\title{
Implications of food-for-work programs for consumption and production diversity: Evidence from the Tigray Region of Ethiopia
}

\author{
Bethelhem Legesse Debela ${ }^{1 *}\left(\mathbb{D}\right.$, Gerald E. Shively ${ }^{2}$ and Stein T. Holden ${ }^{3}$
}

\author{
* Correspondence: bdebela@uni- \\ goettingen.de \\ 'Department of Agricultural \\ Economics and Rural Development, \\ University of Goettingen, Platz der \\ Goettinger Sieben 5, 37073 \\ Goettingen, Germany \\ Full list of author information is \\ available at the end of the article
}

\begin{abstract}
Food-based transfer programs have the potential to change diets or alter basic crop mixes. This study empirically investigates the associations between participating in food-for-work (FFW) programs and the diversity of food consumption and production. Four waves of panel data from the Tigray Region of Northern Ethiopia, covering the period 2001-2010, are used to estimate a series of panel data regressions. A doseresponse model is used to measure how the intensity of FFW participation aligns with dietary outcomes. Results show that FFW participants had greater household dietary diversity compared with non-participants, with an average magnitude equivalent to onefifth of a standard deviation in the food variety score. When items directly provided by the FFW program are excluded from the variety score, the overall effect is statistically weaker, but similar in sign and magnitude, suggesting modest "crowding in" of dietary diversity from FFW participation. FFW participation was not correlated with changes in production diversity, suggesting that the labor demands of the program did not alter crop choice. Findings have relevance for interventions that aim to improve food security and promote dietary quality in low-income populations.
\end{abstract}

Keywords: Dietary diversity, Food-based programs, Food-for-work, Food security, Nutrition, Ethiopia

JEL codes: $138, \mathrm{Q} 12$

\section{Introduction}

Do food-for-work (FFW) programs improve diets or change production practices among participating households? The answer to this question is important because food-based transfer programs have become a standard tool for addressing the problem of chronic food insecurity in low-income settings (Alderman and Mustafa 2013). Food aid has evolved substantially from its origins in providing food surpluses for humanitarian needs to engaging donors from high-income nations in promoting food security, economic development, and social assistance and protection through a range of cash and in-kind transfers (Devereux, 2001; Food and Agriculture Organization (FAO)

(c) The Author(s). 2021 Open Access This article is licensed under a Creative Commons Attribution 4.0 International License, which permits use, sharing, adaptation, distribution and reproduction in any medium or format, as long as you give appropriate credit to the original author(s) and the source, provide a link to the Creative Commons licence, and indicate if changes were made. The images or other third party material in this article are included in the article's Creative Commons licence, unless indicated otherwise in a credit line to the material. If material is not included in the article's Creative Commons licence and your intended use is not permitted by statutory regulation or exceeds the permitted use, you will need to obtain permission directly from the copyright holder. To view a copy of this licence, visit http://creativecommons.org/licenses/by/4.0/. 
2005; Adato and Hoddinott, 2008; Dercon, 2011). By engaging beneficiaries in community infrastructure projects in exchange for food or cash, food-for-work, and cash-for-work programs have become especially attractive to donors and recipients and recognized as potential vehicles for improving nutrition (Rogers and Coates 2002; Nair et al. 2016).

In theory, such programs have the potential to expand dietary diversity, especially if the food items provided by the program are not otherwise part of the staple diet. Consumption of additional varieties of food items is also possible if distributions free up spending that otherwise would have been used to purchase food items provided by the program. By raising effective incomes, cash payments also have the potential to "crowd in" purchases of nutritionally important foods (Bailey 2013; Burchi et al. 2016; de Groot et al. 2017). However, if FFW participation requires a household to divert labor away from on-farm production, such programs have the potential to undermine production diversity by altering the basic crop mix, especially if labor is withdrawn from non-staple food production. ${ }^{1}$ The net effect of these opposing forces is unclear and is the primary investigation in this paper.

The geographic focus of this study is the Tigray Region, in northern Ethiopia, a country that has been a recipient of food assistance with FFW interventions for more than three decades. Historically, food aid provision in Ethiopia took the forms of free food and food-for-work, often in response to drought and subsequent food shortages (Jayne et al. 2001; Caeyers and Dercon 2012). As a result of chronic food insecurity, provision of long-term assistance to vulnerable rural households gradually became part of the food security program of the country. Since 2005, FFW programs in Ethiopia have been administered mainly as part of the country's Productive Safety Net Program (PSNP), a larger and more comprehensive social protection program designed to reach more than five million chronically food-insecure individuals. Large proportions of beneficiaries receive food or cash transfers in exchange for work on public work projects. A smaller proportion (10-15\%, mostly elderly or disabled individuals or pregnant women) receives unconditional transfers (Gilligan et al. 2008; Tigray Food Security Task Force 2009; Berhane et al., 2013).

Hidrobo et al. (2018) review the implications of social protection for food security and asset formation. Rigorous empirical studies conducted in Latin America show potentially positive impacts from transfers. For example, Hoddinott and Wiesmann (2008) and Hoddinott and Skoufias (2004) report that beneficiaries of conditional cash transfers in Honduras, Mexico, and Nicaragua had higher diet quality and Hidrobo et al. (2014) report that cash, food, and voucher transfers improved both the quantity and quality of food consumption in Ecuador.

The empirical record for Africa remains incomplete and mixed. Berlie (2014) argues that Ethiopia's PSNP led to reduced dietary diversity, but Berhane et al. and Berhane et al. (2014) found no PSNP effect on caloric availability or dietary diversity. Using a dietary diversity score and a coping strategy index to classify households as either food secure or food insecure, Uraguchi (2011) found only a limited impact of emergency food

\footnotetext{
${ }^{1}$ Nutrition effects aside, Barrett et al. (2005) argue that these programs have reduced labor supply to agriculture and off-farm activities in Ethiopia, as well as reduced incentives to invest in agriculture. Gelan (2007) also finds a decline in local food production in conjunction with FFW. In contrast, Abdulai et al. (2005) and Bezu and Holden (2008) uncover no strong evidence of FFW disincentives for agricultural production, and Tadesse and Shively (2009) find modest downward pressure on local food prices as a result of FFW interventions.
} 
aid or PSNP participation on food security. Gilligan and Hoddinott (2007) found a positive effect of emergency food aid on food consumption in the aftermath of Ethiopia's 2002 drought, and Berhane et al. (2015) found a positive effect from a pilot program of social cash transfers on dietary diversity in the Tigray Region. Elsewhere in Africa, the Social Cash Transfer Programme pilot in Malawi, the Child Grant Program in Zambia, and the World Food Program's food and cash transfer modalities in Mozambique were all associated with higher household dietary diversity (Miller et al. 2011; American Institutes for Research (AIR) 2013; Zhou and Hendriks 2017). Merttens et al. (2013) report that Kenya's Hunger Safety Net Programme improved dietary diversity of the poorest households, but that the overall impact on the full set of program beneficiaries was limited.

Several empirical investigations link food-for-work programs and food production (Abdulai et al. 2005; Gelan 2007; Bezu and Holden 2008). However, few studies examine the implications of food-for-work on diversity in food production, and those that do are mainly descriptive (e.g., World Food Program 2015; World Food Program 2017; World Food Program 2019). The lack of studies that empirically measure the connection between FFW programs and production diversity is somewhat surprising given that a major requirement of all such programs is that beneficiary households provide labor to local projects, in some cases diverting individuals from other productive activities. The studies that come closest to addressing the concerns of this paper, especially in the context of Ethiopia, have faced data limitations, in terms of both the types of data available and geographic coverage. Berlie (2014) focuses on one district in the Amhara Region and employs cross-sectional data. Uraguchi (2011) uses data from one district each in Amhara and Tigray to examine the effect of transfer projects on food security status before and after the PSNP, but was unable to estimate the direct effect of the PSNP on dietary diversity.

To address this gap in the literature, this paper uses representative panel data from the Tigray Region and panel regression models to identify direct impacts on a dietary diversity indicator. Studies by Berhane et al. (2011), Berhane et al. (2013) and Berhane et al. (2014) use data from four major PSNP regions in Ethiopia to examine the implications of intensity of benefits from the PSNP, measured as the difference in receiving payments for 5 years and 1 year. The approach in this paper differs in that it uses a longer time series of data (starting in 2001 and extending through 2010) and examines the broader implications of participating in FFW programs. To further test the robustness of findings to alternative definitions of treatment, participation in FFW programs is first measured using a binary indicator and then using a continuous measure of treatment, based on total monetary payments a household received from public works participation. Overall, the current study makes two contributions. First, it provides new evidence for Ethiopia, making use of four waves of panel data including periods prior to the start of the PSNP. The use of long panel allows for the control for household fixed effects and pre-PSNP characteristics and thereby improves upon previous estimates of project impacts. Second, it measures the association between food-for-work program participation and production diversity.

\section{Study context, research design, and data}

Food-for-work programs in Ethiopia

Food aid in Ethiopia has traditionally been delivered as free food, with the major portion $(80 \%)$ delivered via food-for-work programs. Able-bodied household members in 
FFW participant households are eligible to take part in community development activities including construction of dams, roads, and conservation structures. In return, participants receive either food (typically wheat and oil) or cash, generally at levels that equate to a sub-market wage rate (Bezu and Holden 2008).

Persistent food shortages and an increase in the number of chronically food-insecure households led donors and the government of Ethiopia to launch the Productive Safety Net Program (PSNP) in 2005 (Nega et al. 2010; Rahmato et al. 2013). The first phase of the program ran between 2005 and 2010. The main goal of the PSNP is to provide long-term support for chronically food-insecure households by providing assistance for a predictable period. Similar to earlier food aid programs, the PSNP includes food-forwork (FFW), cash-for-work (CFW), and unconditional free food. Eligibility for PSNP has generally been determined based on three conditions: (i) whether households faced food gaps or were beneficiaries of food aid three years prior to the start of the program; (ii) whether households faced shocks that caused asset depletion; or (iii) whether the household lacks external support from other safety net programs or family members (Government of Ethiopia 2009; Berhane et al., 2013). Targeting criteria used in both the emergency food aid program and the PSNP can generally be considered indicators of the poverty or food insecurity status of beneficiaries. While the public works program (FFW and CFW) require able-bodied individuals for eligibility, free food distribution targets elderly, disabled or sick individuals, and pregnant and lactating women (Gilligan and Hoddinott 2007; Government of Ethiopia 2009). Although favoritism may exist in the targeting of such programs, prior investigations have found the PSNP to be well-targeted when measured at an international standard, especially in the highlands (Coll-Black et al. 2011; World Bank. 2016). Nevertheless, one cannot rule out the potential for inclusion and exclusion errors in targeting.

Payments can be made in the form of cash, food (wheat and oil), or a combination of both (Sabates-Wheeler and Devereux 2010). The definition of receipt of benefit from FFW prior to the start of the PSNP and after 2005 might differ. While the PSNP has a long-term dimension that provides benefits for 6 months, FFW programs prior to 2005 took the form of emergency relief, whereby benefit periods were shorter. However, since participation in the public works programs was demand driven, the fact that there was high demand from beneficiaries implies that households participated in the program for at least the minimum period supplied by the program (Bezu and Holden 2008). Further, household selection into the PSNP was based on prior receipt of emergency relief program benefits. Therefore, the main impact of participation is likely to come through the total amount of benefits resulting from the program and the outreach.

Most public work programs typically operate during the agricultural off-peak season so as to avoid competing with agricultural work (Berhane et al. 2014). For this reason, one might expect that participation in such programs would not affect production decisions. However, a considerable number of anticipatory agricultural tasks occur in the slack season, among them land preparation and planting, both of which require large amounts of labor in the Ethiopian context. Furthermore, in FFW and CFW settings, smallholder production and consumption decisions are typically linked and rarely made independently (Hoddinott et al. 2014). This implies that food and cash transfers have the potential to affect the production decisions of participating households. On the one 
hand, cash transfers might facilitate purchases of agricultural inputs, which could promote crop diversity. On the other hand, food receipts could affect production decisions, especially for cereals, either by changing planted area or crop mix.

\section{Research design}

Data for this study come from household surveys conducted in 2001, 2003, 2006, and 2010 in the highlands of the Tigray Region, in northern Ethiopia. The initial sample was collected in 1998 using stratified random sampling to select sample households. A total of 16 villages were first sampled from four zones of Tigray Region-central, eastern, western, and south eastern zones. Sample villages are representative of population density, market access, agro-climatic conditions, and agricultural potential (Hagos and Holden 2002). From each village, 25 households were selected randomly making up a total of 400 initial sample households. Follow-up surveys were then carried out in 2001, 2003, 2006, and 2010 by tracking the same households across the survey years. The 2010 survey further included two additional villages from the southern zone. ${ }^{2}$ The last four waves provide the data used for this analysis. The initial survey round was excluded because food reporting was less detailed than in subsequent rounds, thus precluding construction of the main variables of interest (see the next sub-section). Although the same households were followed to the extent possible, it was in some cases impossible to track some households. The main causes of attrition were nonresponse and refusal to respond to the questionnaires. As part of the robustness analyses, tests reported below examine the possibility of attrition bias.

Hired enumerators who spoke the local language used household and village questionnaires to conduct the surveys. Data are comparable across the survey rounds both because all rounds used the same questionnaire and because data collection was undertaken during the same period of time between May and July. Data were collected on household characteristics, food consumption, crop and livestock production, land and non-land asset ownership, livestock and crop sales, off-farm income, food-for-work participation, and PSNP membership.

PSNP membership status was collected in the 2010 survey. For purposes of the analysis, food-for-work participation refers to participation in any public works project that resulted in a household receiving food, cash, or some combination of the two. One subset of the analysis differentiates among households that received food only, cash only, or a combination of food and cash. The dataset consists of an unbalanced sample of 1426 observations (343 households for 2001, 344 for 2003, 315 for 2006, and 424 for 2010).

\section{Measurement of household dietary diversity}

Household dietary diversity was measured using annual recall data on food consumption observed at the household level. A set of 29 food items that were consistently defined and reported across all survey rounds were used to calculate the dietary diversity measure. ${ }^{3}$ Respondents (mainly the household head or spouse) reported the amount of

\footnotetext{
${ }^{2} \mathrm{~A}$ map of the study area is provided as Figure A1 in the Online Appendix.

${ }^{3}$ Three food groups-fruits, tubers and roots, and fishes-had to be excluded from the classification as items in these groups were not consistently defined in all survey rounds. Including them would have created a bias because some items are not reported in some rounds only because these were not asked in the questionnaires.
} 
food items consumed in the previous year based on a list of prompted food items. For each household, a food variety score (FVS) was computed as a simple unweighted count of the number of different food items reported as being consumed by the household in the previous year. ${ }^{4}$ The FVS is the main variable used to compare dietary diversity between households that did and did not participate in the FFW program. Using this count of food items allows us to test whether results are sensitive to the inclusion of items (primarily wheat and oil) provided directly by the food-for-work program. To further examine the diversity of food items in specific food groups, this study follows FAO (2011) and aggregates the 29 food items into nine food groups (cereals; legumes, nuts, and seeds; vegetables; meat; eggs; milk; oil and fats; sweets; spices and condiments).

Typically, payments for food-for-work activities in the study settings are delayed. This may affect measures of dietary diversity if a survey is carried out before payments are made and if it uses weekly or daily scales. For example, Berhane et al. (2011) argue that delays in payment could explain why they do not find positive impacts of payments on calorie availability. In such a case, an annual scale provides the overall quality of diet in the household and allows differentiating between those who are beneficiaries and those who are not. Put differently, using annual reported consumption to generate the FVS captures consumption that would be otherwise underreported due to delayed payment. It is possible that annual recall data may also lead to underreporting of some food items (Ruel 2002; Food and Agriculture Organization (FAO) 2011). However, annual consumption should be representative of a household's overall dietary diversity if households have generally good recall about "hungry periods" and what they could afford to eat during the past year. Although time frames commonly used to assess dietary diversity also include 24-h and 7-day recalls, daily and weekly recall measures were not collected as part of the surveys providing data for this study and therefore it is not possible to compare the annual FVS results with those associated with alternative diet recall periods.

Finally, this study relies on a simple count of the number of food items consumed, rather than actual quantities, and hence, underreporting is not likely to be a problem. It also avoids sensitivity to seasonality in food consumption, which is especially relevant in the Ethiopian context, where fasting and food avoidance (especially of animal products) is widely practiced during some periods of the year. ${ }^{5}$ Using an annual measure avoids underreporting that might arise if shorter recall periods were used to capture consumption that is period specific or highly seasonal.

One shortcoming of using an annual household-level FVS is that the indicator cannot account for differences in gender and age composition across households and does not account for intra-household allocation of food. However, as a broad indicator of overall availability of dietary diversity in the household, which is the focus for this study, the indicator is widely used. One should not conclude, however, that household dietary diversity is indicative of dietary diversity among all household members.

\footnotetext{
${ }^{4}$ According to FAO (2011), pre- and post-intervention measures of dietary diversity collected with the objective of assessing the impact of the intervention should be carried out at the same time of the year. The surveys used in this study are compatible with this criterion. As mentioned, data collection was undertaken at similar times in all survey rounds (between May and July).

${ }^{5}$ Hirvonen et al. (2016) document the link between seasonality and the quantity and quality of diets among Ethiopian households. They find lower dietary diversity during Orthodox fasting seasons.
} 
Measurement of production diversity

Production diversity in this study is measured by counting the number of crops cultivated annually by the household. Five food groups were used: (i) cereals; (ii) legumes, nuts, and seeds; (iii) vegetables; (iv) fruits; and (v) spices.

\section{Characteristics of the sample}

Table 1 presents descriptive statistics for all variables used in the analysis, separately by food-for-work participation status. Of the 1426 household observations, 741 (roughly $50 \%)$ participated in food-for-work programs. Characteristics of households in the two groups differ significantly. Participants in the food-for-work programs own smaller parcels of land and have higher labor endowments (of both female and male labor). This is in line with the requirements for participating in the public work programs whereby less well-off households and those with better labor endowment are prioritized. While livestock ownership is in most cases lower among FFW participants than FFW nonparticipants, the difference is statistically significant only in 2010. The empirical analysis controls for these potentially confounding factors when estimating the implication of FFW participation on consumption and production diversity.

Dietary diversity in the sample is summarized in Table 2, including the average number of food items in each food group $($ mean $=14.4$; standard deviation $=3.9 ; \min =1 ; \max =$ 25). Average dietary diversity is similar across the survey years, except for a slightly lower value observed in 2003, probably because 2003 was a drought year. Table 3 presents production diversity and the number of crops in each food group in each survey round. On average, a household produced three different crops. The maximum number of crops cultivated among the sample households was seven. ${ }^{6}$ As with consumption diversity, production diversity in 2003 was lower than in other years, reflecting the influence of that year's drought.

Table 4 reports average differences in food variety and production diversity scores by participation in FFW programs. FFW participants consume a significantly higher variety of foods compared with the non-participants in FFW programs (see Table 4). When disaggregating FFW participation by survey year, it appears that the difference in the food variety score is driven mostly by changes in 2003, 2006, and 2010. In contrast, Table 4 shows a slight overall difference in production diversity between FFW participants and non-participants driven by the significant difference in the measure of production diversity for the year 2001 (see Table 4). Figures 1 and 2 further illustrate patterns observed in Table 4. The distribution of the FVS is shifted to the right for participants in FFW programs compared with non-participants (Fig. 1). Figure 2 illustrates that participants and non-participants in FFW programs exhibit very similar production diversity.

\footnotetext{
${ }^{6}$ Although the production of khat, a leafy plant which is a stimulant when chewed, has been widely expanding in the country as a cash crop for local consumption and export, khat production is legally controlled in Tigray along with regional states of Benishangul-Gumuz and Gambella (Gebissa 2008; Cochrane and O'Regan 2016). As a result, a switch toward production of khat has not been widely observed in Tigray, as it has been in other regions of Ethiopia.
} 
Table 1 Descriptive statistics

\begin{tabular}{|c|c|c|c|c|c|c|c|c|c|c|c|}
\hline & \multicolumn{3}{|l|}{ All years } & \multicolumn{2}{|l|}{2001} & \multicolumn{2}{|l|}{2003} & \multicolumn{2}{|l|}{2006} & \multicolumn{2}{|l|}{2010} \\
\hline & Mean & $\begin{array}{l}\text { FFW } \\
=1\end{array}$ & $\begin{array}{l}\text { FFW } \\
=0\end{array}$ & $\begin{array}{l}\text { FFW } \\
=1\end{array}$ & $\begin{array}{l}\text { FFW } \\
=0\end{array}$ & $\begin{array}{l}\text { FFW } \\
=1\end{array}$ & $\begin{array}{l}\text { FFW } \\
=0\end{array}$ & $\begin{array}{l}\text { FFW } \\
=1\end{array}$ & $\begin{array}{l}\text { FFW } \\
=0\end{array}$ & $\begin{array}{l}\text { FFW } \\
=1\end{array}$ & $\begin{array}{l}\text { FFW } \\
=0\end{array}$ \\
\hline $\begin{array}{l}\text { Age of household } \\
\text { head (years) }\end{array}$ & 54.05 (14.59) & 52.01 & $55.94^{* * *}$ & 50.45 & $56.04^{* * *}$ & 51.80 & $54.55^{*}$ & 53.79 & $56.76^{*}$ & 52.30 & $56.76^{* * *}$ \\
\hline $\begin{array}{l}\text { Female-headed } \\
\text { household }(0 / 1)\end{array}$ & $0.28(0.45)$ & 0.22 & $0.33^{* * *}$ & 0.22 & $0.34^{* *}$ & 0.21 & $0.32^{* *}$ & 0.21 & $0.38^{* * *}$ & 0.23 & $0.31^{*}$ \\
\hline $\begin{array}{l}\text { Education of } \\
\text { head }(0 / 1)\end{array}$ & $0.31(0.46)$ & 0.32 & 0.30 & 0.38 & $0.27^{* *}$ & 0.26 & $0.37^{* *}$ & 0.36 & 0.28 & 0.25 & 0.27 \\
\hline $\begin{array}{l}\text { Adult female } \\
\text { labor (\#) }\end{array}$ & $1.37(0.85)$ & 1.51 & $1.24^{* * *}$ & 1.48 & $1.14^{* * *}$ & 1.42 & $1.26^{*}$ & 1.59 & $1.22^{* * *}$ & 1.54 & $1.31^{* * *}$ \\
\hline $\begin{array}{l}\text { Adult male } \\
\text { labor (\#) }\end{array}$ & 1.39 (1.13) & 1.58 & $1.22^{* * *}$ & 1.53 & $1.22^{* *}$ & 1.56 & $1.24^{* * *}$ & 1.72 & $1.09^{* * *}$ & 1.55 & $1.22^{* *}$ \\
\hline Children (\#) & $2.10(1.61)$ & 2.41 & $1.82^{* * *}$ & 2.76 & $1.92^{* * *}$ & 2.66 & $2.17^{* * *}$ & 1.88 & $1.26^{* * *}$ & 2.32 & $1.80^{* * *}$ \\
\hline $\begin{array}{l}\text { Land area } \\
\text { owned (Tsimdi)a }\end{array}$ & $4.61(3.41)$ & 4.39 & $4.81^{* *}$ & 4.51 & 4.60 & 4.64 & 4.86 & 4.35 & 4.60 & 4.15 & $5.04^{* *}$ \\
\hline Livestock (TLUs) ${ }^{b}$ & $3.17(3.31)$ & 3.14 & 3.19 & 4.12 & 4.38 & 2.64 & 2.66 & 2.74 & 2.57 & 2.78 & $3.43^{* *}$ \\
\hline $\begin{array}{l}\text { Off-farm } \\
\text { income }(0 / 1)\end{array}$ & $0.50(0.50)$ & 0.50 & 0.50 & 0.77 & 0.76 & 0.38 & 0.37 & 0.41 & 0.48 & 0.36 & $0.47^{* *}$ \\
\hline $\begin{array}{l}\text { Number of } \\
\text { observations }\end{array}$ & 1426 & 741 & 685 & 203 & 140 & 117 & 227 & 156 & 159 & 209 & 215 \\
\hline
\end{tabular}

${ }^{\mathrm{a}} 1 \mathrm{Tsimdi}=0.25 \mathrm{ha} ;{ }^{\mathrm{b}}$ Tropical livestock units (calculated based on Ayalew et al. 2003). * significant at $10 \%$; ** significant at $5 \%$; ${ }^{* * *}$ significant at $1 \%$

\section{Methods of data analysis}

\section{Econometric model}

\section{General setup}

The goal in this paper is to estimate the implication of FFW participation on diversity in food consumption and production. The general specification employs two sets of regressions; one set each for dietary diversity (Model 1) and production diversity (Model 2). The regressions take the form:

$$
\begin{aligned}
& D D_{i t}=\beta_{0}+\beta_{1}^{\prime} \mathbf{X}_{i t}+\beta_{2}^{\prime} \mathbf{A}_{i t}+\beta_{3} F F W_{i t}+\beta_{4}^{\prime} \mathbf{T}+a_{i}+\varepsilon_{i t} \\
& P D_{i t}=\beta_{0}+\beta_{1}^{\prime} \boldsymbol{X}_{i t}+\beta_{2}^{\prime} \mathbf{A}_{i t}+\beta_{3} F F W_{i t}+\beta_{4}^{\prime} \mathbf{T}+a_{i}+\varepsilon_{i t}
\end{aligned}
$$

\begin{tabular}{|c|c|c|c|c|c|c|c|}
\hline & All & Min & Max & 2001 & 2003 & 2006 & 2010 \\
\hline Food variety score & $14.35(3.93)$ & 1 & 25 & $14.52(4.05)$ & $12.89(4.10)$ & $14.63(3.58)$ & $15.17(3.61)$ \\
\hline \multicolumn{8}{|l|}{ Number of items in food groups } \\
\hline Cereals $^{\mathrm{a}}$ & $3.25(1.13)$ & 0 & 6 & $3.33(1.11)$ & 2.99 (1.09) & $3.60(1.21)$ & $3.14(1.04)$ \\
\hline Legumes, nuts, and seeds ${ }^{\mathrm{b}}$ & $1.47(1.00)$ & 0 & 6 & $1.86(1.08)$ & $1.19(0.89)$ & $1.37(1.05)$ & $1.46(0.86)$ \\
\hline Vegetables $^{c}$ & 2.09 (1.19) & 0 & 4 & $1.71(1.16)$ & $1.46(1.13)$ & $2.51(0.96)$ & $2.60(1.09)$ \\
\hline Meat $^{d}$ & $1.91(0.81)$ & 0 & 4 & $1.85(0.79)$ & $1.83(0.84)$ & $1.88(0.83)$ & $2.04(0.76)$ \\
\hline Eggs & $0.40(0.49)$ & 0 & 1 & $0.40(0.49)$ & $0.28(0.45)$ & $0.42(0.49)$ & $0.47(0.50)$ \\
\hline Milk & $0.15(0.35)$ & 0 & 1 & $0.14(0.35)$ & $0.06(0.25)$ & $0.17(0.37)$ & $0.21(0.41)$ \\
\hline Oil and fats ${ }^{\mathrm{e}}$ & $1.26(0.65)$ & 0 & 2 & $1.38(0.71)$ & $1.09(0.75)$ & $1.32(0.60)$ & $1.26(0.51)$ \\
\hline Sweets $^{f}$ & $0.57(0.49)$ & 0 & 1 & $0.73(0.45)$ & $0.79(0.41)$ & $0.03(0.17)$ & $0.68(0.47)$ \\
\hline Spices and condiments ${ }^{g}$ & $3.25(0.81)$ & 0 & 4 & $3.11(0.78)$ & $3.20(0.81)$ & $3.34(0.82)$ & $3.32(0.80)$ \\
\hline Number of observations & 1426 & & & 343 & 344 & 315 & 424 \\
\hline
\end{tabular}

Table 2 Dietary diversity in the sample

Standard deviations in parentheses. ${ }^{a}$ Teff, wheat, barley, maize, sorghum, millet; ${ }^{b}$ favabean, chickpea, pea, lentil, latyrus; ${ }^{c}$ cabbage, onion, tomato, garlic; ${ }^{d}$ beef, sheep, goat, chicken; ${ }^{e}$ oil and butter; ${ }^{f}$ sugar; ${ }^{9}$ pepper, coffee, spice, salt 
Table 3 Production diversity in the sample

\begin{tabular}{llllllll}
\hline & Mean & Min & Max & 2001 & 2003 & 2006 & 2010 \\
\hline $\begin{array}{l}\text { Production diversity score } \\
\text { Number of crops in food groups }\end{array}$ & $2.63(1.17)$ & 0 & 7 & $2.72(1.13)$ & $2.41(1.12)$ & $2.73(1.31)$ & $2.67(1.12)$ \\
Cereals $^{\mathrm{a}}$ & $2.22(0.92)$ & 0 & 5 & $2.31(0.90)$ & $2.03(0.86)$ & $2.37(1.00)$ & $2.17(0.89)$ \\
Legumes, nuts and seeds $^{\mathrm{b}}$ & $0.33(0.55)$ & 0 & 3 & $0.30(0.53)$ & $0.33(0.57)$ & $0.30(0.54)$ & $0.38(0.57)$ \\
Vegetables $^{c}$ & $0.06(0.23)$ & 0 & 1 & $0.03(0.16)$ & $0.04(0.19)$ & $0.04(0.20)$ & $0.11(0.31)$ \\
Fruits $_{\text {Spices }}^{\mathrm{e}}$ & $0.004(0.06)$ & 0 & 1 & $0.003(0.05)$ & $0.01(0.08)$ & $0.003(0.06)$ & $0.002(0.05)$ \\
Number of observations & $0.03(0.16)$ & 0 & 1 & $0.07(0.26)$ & $0.01(0.11)$ & $0.01(0.11)$ & $0.01(0.11)$ \\
\hline
\end{tabular}

Standard deviations in parentheses. ${ }^{\mathrm{a} T e f f}$, wheat, barley, maize, sorghum, millet; ${ }^{\mathrm{b} l e g u m e s,}$ nuts, and seeds: field pea, bean, linseed, lentil; 'onion; ${ }^{d}$ papaya; ${ }^{\text {epepper }}$

where in Eqs. (1) and (2), $D D_{i t}$ and $P D_{i t}$ represent dietary diversity and production diversity for household $i$ at time $t$, respectively. As defined in "Study context, research design, and data," the dependent variables are measured as count variables of food items consumed and produced. ${ }^{7} \mathbf{X}_{i t}$ represents a vector of household characteristics (age, sex, and education of the household head; the number of children, the number of adult females and males; and a binary indicator for participation in off-farm activities), $\mathbf{A}_{i t}$ denotes asset indicators (land area owned and livestock ownership). $F F W_{i t}$ is a binary indicator for participation in food-for-work or cash-for-work programs. In this setup, the treatment groups are households that benefited either from the food-for-work or cash-for-work programs and the control groups are households that received none of these benefits. $\mathbf{T}$ is a vector of survey year indicators, and $\varepsilon_{i t}$ represents an idiosyncratic error with expected value of zero.

\section{Choice of estimators}

To choose an appropriate model specification for the panel data analyses, a Hausman test was used to compare the performance of random effects and fixed effects estimators for these data. The test indicates that differences in the coefficients between the two specifications are systematic, and therefore favors a household fixed effects estimator, which is used as the main model to control for time-invariant unobserved heterogeneity. In Eqs. (1) and (2), $a_{i}$ is a time-invariant unobserved effect, which is differenced out when performing fixed effects estimation.

It is possible that, over the course of the surveys, some households could have switched into or out of the FFW program. To address this possibility, in addition to the fixed effect models, a model using a difference-in-difference (DID) approach is also estimated by taking the first differences of the dependent and independent variables. This

\footnotetext{
${ }^{7}$ Although count models are also suitable for estimating Eqs. (1) and (2), and in some cases might be preferred, the variables in this study fulfill the conditions for estimating linear models. First, both the food variety score and production diversity score variables are normally distributed making it suitable to model using a linear model. According to Wooldridge (2010, p. 596), this normality assumption is suitable for a continuous dependent variable that takes a large range of values. Second, the food variety score does not contain zero values and the values are not bounded to zero. While the production diversity score contains zero values, and takes relatively fewer values, the number of zero values is extremely small (0.28\%). Further, in both cases, greater than $50 \%$ of the observations have values above the mean food variety score and production diversity score and hence are not bound to zero. On this basis, this study uses linear models in panel data setup. Nevertheless, Poisson regressions for both models showed consistent results, both in terms of signs and significance.
} 
Table 4 Dietary diversity and production diversity by food-for-work participation

\begin{tabular}{|c|c|c|c|}
\hline & Food variety score (FVS) & Production diversity score (PDS) & Number of observations \\
\hline All years & $14.35(0.10)$ & $2.63(0.03)$ & 1426 \\
\hline $\mathrm{FFW}=1$ & $14.87(0.14)$ & $2.71(0.04)$ & 685 \\
\hline $\mathrm{FFW}=0$ & $13.85(0.15)$ & $2.56(0.04)$ & 741 \\
\hline Diff & $1.01^{* * *}$ & $0.14^{* *}$ & \\
\hline 2001 & $14.52(0.22)$ & $2.72(0.06)$ & 343 \\
\hline $\mathrm{FFW}=1$ & $14.81(0.27)$ & $2.80(0.08)$ & 203 \\
\hline $\mathrm{FFW}=0$ & $14.09(0.36)$ & $2.59(0.09)$ & 140 \\
\hline Diff & 0.73 & $0.21^{*}$ & \\
\hline 2003 & $12.89(0.22)$ & $2.41(0.06)$ & 344 \\
\hline $\mathrm{FFW}=1$ & $13.40(0.34)$ & $2.51(0.11)$ & 117 \\
\hline $\mathrm{FFW}=0$ & $12.63(0.28)$ & $2.36(0.07)$ & 227 \\
\hline Diff & $0.78^{*}$ & 0.15 & \\
\hline 2006 & $14.63(0.20)$ & $2.73(0.07)$ & 315 \\
\hline $\mathrm{FFW}=1$ & $15.10(0.23)$ & $2.77(0.10)$ & 156 \\
\hline $\mathrm{FFW}=0$ & $14.18(0.33)$ & $2.69(0.11)$ & 159 \\
\hline Diff & $0.91^{* *}$ & 0.08 & \\
\hline 2010 & $15.17(0.18)$ & $2.67(0.05)$ & 424 \\
\hline $\mathrm{FFW}=1$ & $15.58(0.24)$ & $2.67(0.07)$ & 209 \\
\hline$F F W=0$ & $14.78(0.25)$ & $2.67(0.08)$ & 215 \\
\hline Diff & $0.81^{* *}$ & 0.01 & \\
\hline
\end{tabular}

Standard errors in parentheses. * significant at 10\%; ** significant at 5\%; *** significant at $1 \%$

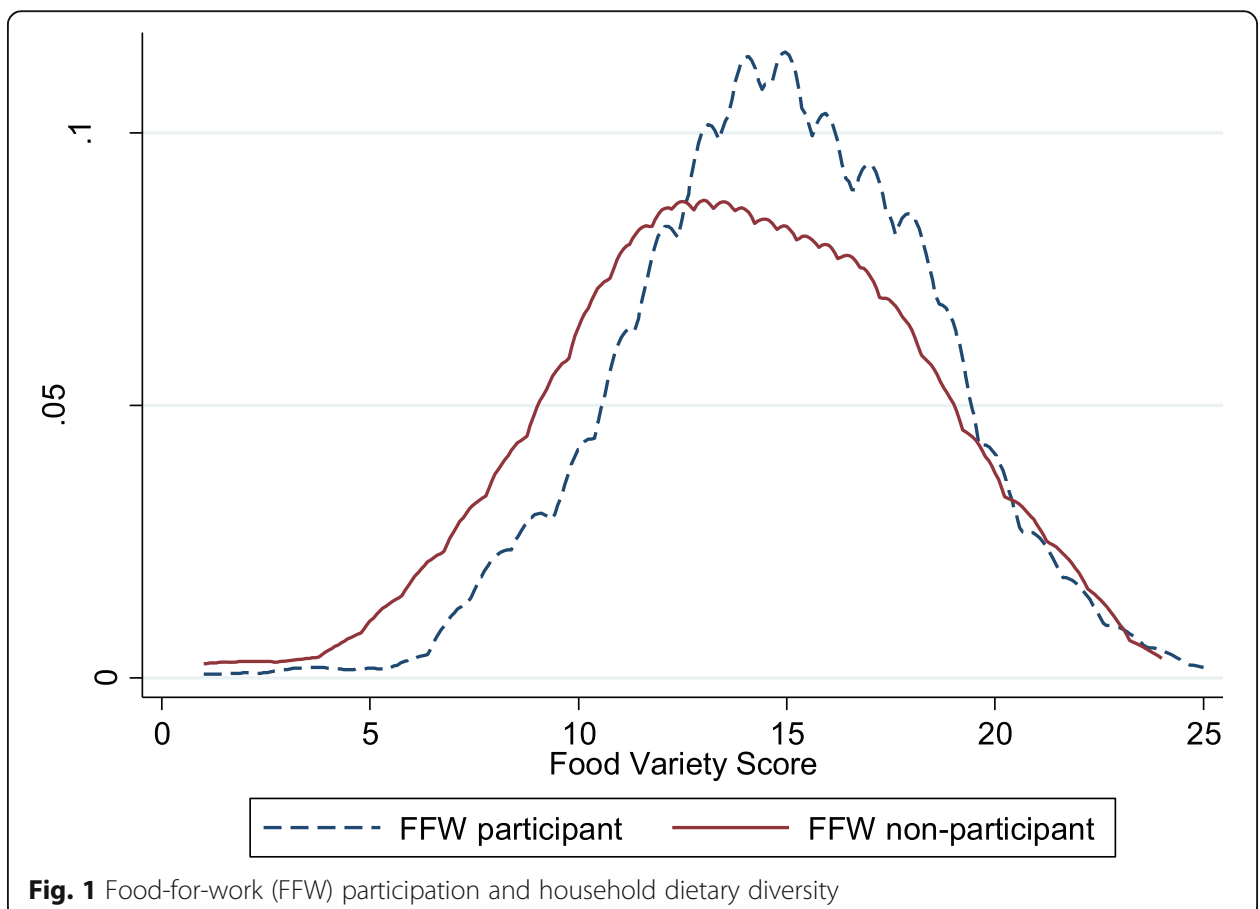

Fig. 1 Food-for-work (FFW) participation and household dietary diversity 


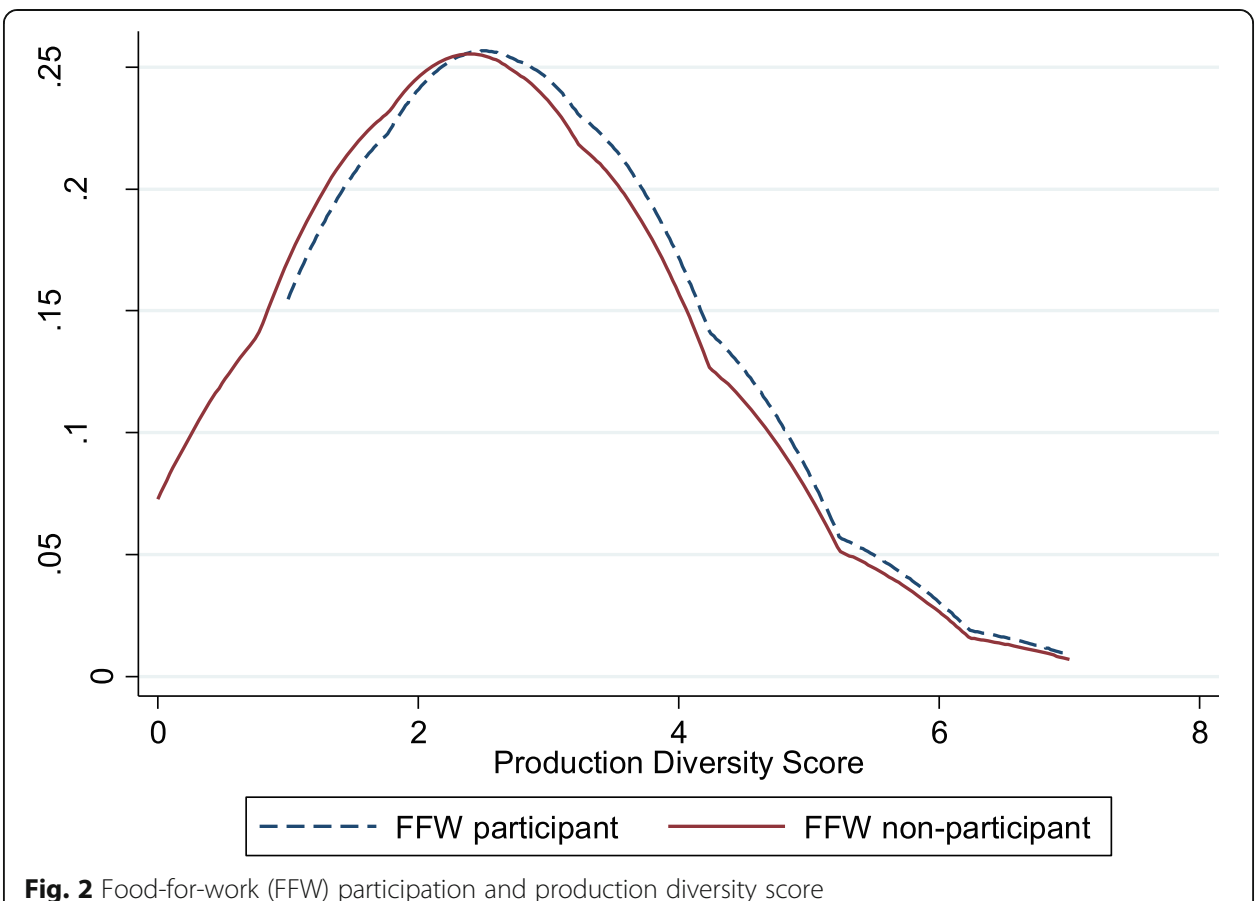

eliminates the unobserved effect, $a_{i}$, by differencing adjacent periods (Wooldridge 2010). The model takes the following form:

$$
\begin{aligned}
& \Delta D D_{i t}=\beta_{0}+\beta_{1}^{\prime} \Delta \mathbf{X}_{i t}+\beta_{2}^{\prime} \Delta \mathbf{A}_{i t}+\beta_{3} \Delta F F W_{i t}+\beta_{4}^{\prime} \mathbf{T}+\Delta \varepsilon_{i t} \\
& \Delta P D_{i t}=\beta_{0}+\beta_{1}^{\prime} \Delta \mathbf{X}_{i t}+\beta_{2}^{\prime} \Delta \mathbf{A}_{i t}+\beta_{3} \Delta F F W_{i t}+\beta_{4}^{\prime} \mathbf{T}+\Delta \varepsilon_{i t}
\end{aligned}
$$

where $t=2003,2006$, and 2010, and the first set of differences is taken between 2003 and 2001. T in Eqs. (3) and (4) control for years 2006 and 2010.

Interpreting observed association as evidence of causal effects of program participation is generally not possible when unobserved heterogeneity in household participation cannot be fully ruled out. As outlined above, this study attempts to address this potential endogeneity issue using fixed effects estimation and DID, both of which control for time-invariant unobserved heterogeneity. However, these approaches cannot address time-varying unobserved heterogeneity. Reported correlations should not, therefore, be read as claims of causal effects. In "Results and discussion," results from random effects models are presented as robustness checks along with additional analyses to assess the consistency of the results under alternative specifications and variable definitions.

\section{Analysis of linkages using continuous treatment}

In order to investigate whether the intensity of participation, rather than participation itself, is associated with dietary diversity, $F F W_{i t}$ in Eqs. (1) and (2) is replaced with the monetary equivalent of the public work benefits (FFW income). In addition, a doseresponse model is fit using a control function regression to measure the relationship between FFW income and dietary diversity. The approach closely follows Cerulli (2015) and is attractive because the dose-response analysis does not require an assumption of 
full normality and is suitable when a substantial proportion of the sample population has a treatment level of zero. The model is specified as:

$$
\left\{\begin{array}{l}
F F W_{i}=1: \quad D D_{1 i}=\mu_{1}+g_{1}\left(\mathbf{x}_{i}\right)+h\left(m_{i}\right)+e_{1} \\
F F W_{i}=0: \quad D D_{0 i}=\mu_{0}+g_{0}\left(\mathbf{x}_{i}\right)+e_{0}
\end{array}\right.
$$

where $g_{1}\left(\mathbf{x}_{i}\right)$ and $g_{0}\left(\mathbf{x}_{i}\right)$ represent functions of the vector of regressors for FFW participants and non-participants and $h\left(m_{i}\right)$ is the function of the monetary equivalent income from FFW, i.e., a continuous treatment that equals zero when $\mathrm{FFW}=0$. The dose in this case is the amount of public work income per adult equivalent and the response is the dietary diversity measure $\left(D D_{i}\right)$. The average treatment effect, given the level of treatment, is:

$$
\operatorname{ATE}(x, m)=E\left(D D_{1 i}-D D_{0 i} \mid x, m\right)
$$

$\operatorname{ATE}(x, m)$ is used to calculate the dose-response function.

\section{Analysis of possible dietary mechanisms}

Multiple channels might exist affecting the link between the food-based programs and dietary outcomes. To better understand the underlying mechanisms, this study undertakes two analyses. First, it assesses whether results differ when food items provided under the FFW program (wheat and oil) are excluded from the calculation of food variety score. For this purpose, a variant of Eq. (1) is estimated that excludes FFW items (wheat and oil) from the dependent variable. Second, it examines whether the estimated impacts among food-for-work (FFW) and cash-for-work (CFW) beneficiaries differ. According to Bailey (2013), the effect of public works programs on consumption depends on the form of transfer, i.e., food or cash. To check this, this study repeats the estimations based on Eq. (1) but controlling for these groups (FFW only, CFW only, and combination of FFW and CFW).

\section{Results and discussion}

\section{Links between FFW participation and dietary diversity}

Table 5 presents fixed effects, random effects, and DID regression results for dietary diversity. The three models are presented for comparison but the main interpretations of results are based on the fixed effects specification. ${ }^{8}$ Findings reveal that households participating in food-for-work programs have significantly higher dietary diversity compared with non-participants. Participation in the FFW program is associated with a 0.86-point higher food variety score, on average, or roughly one additional item in a basket that averages 14 items (see Model 1A). This is equivalent to $22 \%$ of a standard deviation in the food variety score. Table 5 also reveals that dietary diversity is higher for households with an educated household head. The result implies that education of the head is associated with the addition of approximately one additional food item to the households' diet. Adult female labor is positively and significantly associated with a higher diversity of food consumption. An implication is that female members, who are primarily responsible for the purchase and preparation of food, contribute to the

${ }_{8}^{8}$ Results of a Hausman test indicating a fixed effects specification is favored over a random effects specification. 
Table 5 Effect of food-for-work participation on dietary diversity-Binary treatment

\begin{tabular}{|c|c|c|c|}
\hline & $\begin{array}{l}\text { Fixed effects } \\
\text { Model 1A }\end{array}$ & $\begin{array}{l}\text { Random effects } \\
\text { Model 1B }\end{array}$ & $\begin{array}{l}\text { DID }^{\mathbf{b}} \\
\text { Model 1C }\end{array}$ \\
\hline \multirow[t]{2}{*}{ Food-for-work participant (0/1) } & $0.86^{* * *}$ & $0.56^{* * *}$ & $0.68^{* * *}$ \\
\hline & $(0.24)$ & $(0.20)$ & $(0.24)$ \\
\hline \multirow[t]{2}{*}{ Age of household head (years) } & -0.02 & $-0.02^{* *}$ & $-0.06^{* *}$ \\
\hline & $(0.02)$ & $(0.01)$ & $(0.02)$ \\
\hline \multirow[t]{2}{*}{ Female-headed household (0/1) } & -0.15 & -0.43 & -0.32 \\
\hline & $(0.47)$ & $(0.28)$ & $(0.49)$ \\
\hline \multirow[t]{2}{*}{ Education of head $(0 / 1)$} & $0.96^{* *}$ & $0.72^{* * *}$ & 0.72 \\
\hline & $(0.37)$ & $(0.24)$ & $(0.45)$ \\
\hline \multirow[t]{2}{*}{ Adult female labor (\#) } & $0.28^{*}$ & $0.34^{* * *}$ & $0.39^{*}$ \\
\hline & $(0.17)$ & $(0.12)$ & $(0.20)$ \\
\hline \multirow[t]{2}{*}{ Adult male labor (\#) } & 0.11 & $0.21^{* *}$ & 0.20 \\
\hline & $(0.15)$ & $(0.10)$ & $(0.17)$ \\
\hline \multirow[t]{2}{*}{ Children (\#) } & 0.18 & $0.15^{* *}$ & $0.23^{* *}$ \\
\hline & $(0.11)$ & $(0.08)$ & $(0.12)$ \\
\hline \multirow[t]{2}{*}{ Land area owned $\left(\right.$ Tsimdi) ${ }^{a}$} & 0.03 & $0.16^{* * *}$ & 0.03 \\
\hline & $(0.05)$ & $(0.03)$ & $(0.06)$ \\
\hline \multirow[t]{2}{*}{ Livestock owned (TLUs) } & 0.01 & $0.13^{* * *}$ & -0.01 \\
\hline & $(0.05)$ & $(0.04)$ & $(0.07)$ \\
\hline \multirow[t]{2}{*}{ Off-farm income (0/1) } & 0.28 & $0.43^{* *}$ & 0.33 \\
\hline & $(0.23)$ & $(0.20)$ & $(0.26)$ \\
\hline \multirow[t]{2}{*}{2003} & $-1.27^{* * *}$ & $-1.08^{* * *}$ & \\
\hline & $(0.29)$ & $(0.27)$ & \\
\hline \multirow[t]{2}{*}{2006} & $0.61^{* *}$ & $0.75^{* * *}$ & $3.24^{* * *}$ \\
\hline & $(0.30)$ & $(0.27)$ & $(0.46)$ \\
\hline \multirow[t]{2}{*}{2010} & $1.13^{* * *}$ & $1.22^{* * *}$ & $2.18^{* * *}$ \\
\hline & $(0.29)$ & $(0.26)$ & $(0.43)$ \\
\hline \multirow[t]{2}{*}{ Zone 2} & & $-0.82^{* *}$ & \\
\hline & & $(0.33)$ & \\
\hline \multirow[t]{2}{*}{ Zone 3} & & -0.27 & \\
\hline & & $(0.34)$ & \\
\hline \multirow[t]{2}{*}{ Zone 4} & & -0.43 & \\
\hline & & $(0.34)$ & \\
\hline \multirow[t]{2}{*}{ Zone 5} & & $-1.49^{* *}$ & \\
\hline & & $(0.58)$ & \\
\hline \multirow[t]{2}{*}{ Constant } & $13.66^{* * *}$ & $12.87^{* * *}$ & $-1.39^{* * *}$ \\
\hline & $(1.10)$ & $(0.71)$ & $(0.31)$ \\
\hline Number of obs. & 1426 & 1426 & 912 \\
\hline Number of groups & 514 & 514 & 371 \\
\hline$R^{2}$ (overall) & 0.14 & 0.20 & 0.14 \\
\hline
\end{tabular}

Standard errors in parentheses. ${ }^{*}$ significant at $10 \%$; ${ }^{* *}$ significant at $5 \%$; ${ }^{* *}$ significant at $1 \% .{ }^{\mathrm{a}} 1 \mathrm{Tsimdi}=0.25$ hectare; Hausman test $\left(X^{2}=31.8, p\right.$-value $\left.=0.003\right) ;{ }^{b}$ In DID model, standard errors are clustered by household ID 
quality of diet in the household. Survey round indicators reveal that consumption diversity declined significantly in 2003 compared with 2001. Dietary diversity in subsequent years increased, with the largest increase in 2010.

\section{Exploring underlying dietary mechanisms}

If households would not otherwise consume food items provided under a food-forwork program, improvements in dietary diversity may arise directly as a result of foods provided by the program, namely wheat and oil. In Table 6, the fixed effects regression for food variety score (FVS) excludes the FFW food items (wheat and oil). Results indicate that participation in the public works program is still positively and significantly associated with dietary diversity, although the magnitude declines by 0.15 points, or approximately $17 \%$.

Table 7 summarizes results for tests of differences in the average number of food groups consumed with and without FFW food items. The significant difference in cereal consumption between FFW participants and non-participants disappears once wheat is excluded from the calculation. This implies that the difference in cereal consumption among FFW participants and non-participants is attributed to the wheat received under the FFW. Table 7 also shows that FFW participants had significantly higher consumption of other food items such as vegetables, meat, eggs, butter, spices, and condiments. One can infer from this that FFW participants were able to add other food items, possibly by reallocating expenditures that would have otherwise been used for food items provided under FFW. This has a positive implication for the food security of vulnerable rural households. In an evaluation of the pilot program of cash transfer in the Tigray Region, Berhane et al. (2015) found that the diversity of food consumed by beneficiaries improved because the program allowed them to purchase a greater diversity of food items. Consumption of milk, sweets, legumes, nuts, and seeds is not significantly different between participants and non-participants of the FFW program. One possible explanation may be that households do not readily add these food groups when expanding their diets.

To further investigate the mechanism through which higher dietary diversity is observed among public work participants, Table 8 summarizes the regression result that controls for households' classification based on whether they receive benefits under food-for-work, cash-for-work, or both. Findings show that the benefit from food-forwork mainly contributes to the improved dietary diversity in households participating in public work programs. This finding, however, is not conclusive because the cash-forwork component of the public works program was not in full operation in all survey years but instead had greater coverage in the later survey years. This is confirmed by interaction terms between year indicators and program components, which are positive and significant for both cash and food programs in $2010 .^{9}$

\section{Analysis of linkages using continuous treatment}

Table 9 presents results for the link between the continuous treatment of FFW income per adult equivalent and dietary diversity. Findings reveal that dietary diversity

\footnotetext{
${ }^{9}$ Isolating the sample for PSNP years only (2006 and 2010) does not show consistently significant results (see Table A1 in the Online Appendix).
} 
Table 6 Effect of food-for-work participation on dietary diversity (fixed effects models with and without food items (i.e., wheat and oil) from food-for-work distribution)

\begin{tabular}{|c|c|c|}
\hline & $\begin{array}{l}\text { With FFW food items } \\
\text { Model } 1 \mathrm{~A}\end{array}$ & $\begin{array}{l}\text { Without FFW food items } \\
\text { Model 1F }\end{array}$ \\
\hline \multirow[t]{2}{*}{ Food-for-work participant $(0 / 1)$} & $0.86^{* * *}$ & $0.71^{* * *}$ \\
\hline & $(0.24)$ & $(0.23)$ \\
\hline Household characteristics & Yes & Yes \\
\hline Binary controls for years & Yes & Yes \\
\hline \multirow[t]{2}{*}{ Constant } & $13.66^{* * *}$ & $12.55^{* * *}$ \\
\hline & $(1.10)$ & $(1.04)$ \\
\hline Number of households & 1426 & 1426 \\
\hline Number of groups & 514 & 514 \\
\hline$R^{2}$ (overall) & 0.14 & 0.13 \\
\hline
\end{tabular}

Standard errors in parentheses. ${ }^{*}$ significant at $10 \%$; ${ }^{* *}$ significant at $5 \%$; ${ }^{* *}$ significant at $1 \%$

increases with higher income from FFW. The magnitude of influence is however small. A $1 \%$ increase in FFW income per adult equivalent increases food variety score by 0.001. The dose-response model (Cerulli 2015), which is summarized in Table A2 in the Online Additional File 1, also shows a positive and significant average treatment effect. This implies that FFW has on average a positive link with food variety score when considering all values of FFW income. The dose-response function plot in Fig. 3 illustrates that FVS is weakly increasing as FFW income increases, especially at higher values of FFW income. The precision of the estimated relationship declines sharply at higher values of the treatment, for which observations are scarce.

Table 7 Dietary diversity with and without food items from food-for-work (wheat and oil)

\begin{tabular}{|c|c|c|c|c|c|c|c|c|}
\hline & \multicolumn{4}{|c|}{ With FFW food items } & \multicolumn{4}{|c|}{ Without FFW food items } \\
\hline & All & $\mathrm{FFW}=1$ & $\mathrm{FFW}=0$ & Diff & All & $\mathrm{FFW}=1$ & $\mathrm{FFW}=0$ & Diff \\
\hline Food variety score (FVS) & 14.35 & 14.87 & 13.86 & $* * *$ & 12.78 & 13.21 & 12.38 & $* * *$ \\
\hline \multicolumn{9}{|c|}{ Number of items in each food groups or dummy for any } \\
\hline Cereals $^{a}$ & 3.25 & 3.36 & 3.15 & *** & 2.47 & 2.52 & 2.42 & \\
\hline Legumes, nuts and seeds ${ }^{\mathrm{b}}$ & 1.47 & 1.51 & 1.43 & & 1.47 & 1.51 & 1.43 & \\
\hline$V^{\text {Vegetables }}{ }^{c}$ & 2.09 & 2.21 & 1.98 & $* * *$ & 2.09 & 2.21 & 1.98 & $* * *$ \\
\hline Meat $^{d}$ & 1.91 & 1.98 & 1.84 & $* * *$ & 1.91 & 1.98 & 1.84 & $* * *$ \\
\hline Eggs & 0.40 & 0.44 & 0.36 & $* * *$ & 0.40 & 0.44 & 0.36 & $* * *$ \\
\hline Milk & 0.15 & 0.15 & 0.14 & & 0.15 & 0.15 & 0.14 & \\
\hline Oil and fats ${ }^{e}$ & 1.26 & 1.35 & 1.18 & $* * *$ & 0.47 & 0.53 & 0.43 & $* * *$ \\
\hline Sweets ${ }^{f}$ & 0.57 & 0.57 & 0.57 & & 0.57 & 0.57 & 0.57 & \\
\hline Spices and condiments ${ }^{9}$ & 3.25 & 3.30 & 3.20 & $* *$ & 3.25 & 3.30 & 3.20 & $* *$ \\
\hline $\begin{array}{l}\text { Proteins (= } 1 \text { for consumption } \\
\text { of eggs, meat, or milk) }\end{array}$ & 0.94 & 0.97 & 0.92 & $* * *$ & 0.94 & 0.97 & 0.92 & $* * *$ \\
\hline Number of observations & 1426 & 685 & 741 & & 1426 & 685 & 741 & \\
\hline
\end{tabular}

Standard deviations in parentheses. ${ }^{*}$ significant at 10\%; ${ }^{*}$ significant at $5 \%$; ${ }^{* *}$ significant at $1 \%{ }^{a}$ Teff, wheat, barley, maize, sorghum, millet; ${ }^{b}$ fava bean, chickpea, pea, lentil, latyrus; ${ }^{c}$ cabbage, onion, tomato, garlic; ${ }^{d}$ beef, sheep, goat,

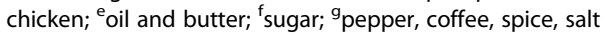


Table 8 Effects of participation in food-for-work versus cash-for-work on household dietary diversity (fixed effects models)

\begin{tabular}{|c|c|c|}
\hline & $(1)$ & $(2)$ \\
\hline \multirow[t]{2}{*}{ Food-for-work only $(0 / 1)$} & $0.98^{* * *}$ & $0.62^{*}$ \\
\hline & $(0.25)$ & $(0.33)$ \\
\hline \multirow[t]{2}{*}{ Cash-for-work only (0/1) } & 0.43 & -1.40 \\
\hline & $(0.50)$ & $(1.06)$ \\
\hline \multirow[t]{2}{*}{ Both food-and cash-for work (0/1) } & 0.44 & 0.96 \\
\hline & $(0.52)$ & $(1.10)$ \\
\hline \multirow[t]{2}{*}{ Food-for-work only $(0 / 1)^{*}$ year2006 } & & 0.21 \\
\hline & & $(0.56)$ \\
\hline \multirow[t]{2}{*}{ Cash-for-work only $(0 / 1)^{*}$ year2006 } & & 1.78 \\
\hline & & $(1.30)$ \\
\hline \multirow[t]{2}{*}{ Both food-and cash-for work $(0 / 1)^{*}$ year2006 } & & -0.58 \\
\hline & & $(1.72)$ \\
\hline \multirow[t]{2}{*}{ Food-for-work only $(0 / 1)^{*}$ year2010 } & & $1.41^{* *}$ \\
\hline & & $(0.61)$ \\
\hline \multirow[t]{2}{*}{ Cash-for-work only $(0 / 1)^{*}$ year2010 } & & $3.36^{* *}$ \\
\hline & & $(1.40)$ \\
\hline \multirow[t]{2}{*}{ Both food-and cash-for work $(0 / 1)^{*}$ year2010 } & & -0.34 \\
\hline & & $(1.23)$ \\
\hline \multirow[t]{2}{*}{2003} & $-1.20^{* * *}$ & $-1.25^{* * *}$ \\
\hline & $(0.29)$ & $(0.31)$ \\
\hline \multirow[t]{2}{*}{2006} & $0.69^{* *}$ & 0.56 \\
\hline & $(0.30)$ & $(0.41)$ \\
\hline \multirow[t]{2}{*}{2010} & $1.26^{* * *}$ & $0.66^{*}$ \\
\hline & $(0.31)$ & $(0.40)$ \\
\hline Household characteristics & Yes & Yes \\
\hline \multirow[t]{2}{*}{ Constant } & $13.52^{* * *}$ & $13.54^{* * *}$ \\
\hline & $(1.10)$ & $(1.11)$ \\
\hline Number of households (groups) & $1426(514)$ & $1426(514)$ \\
\hline$R^{2}$ (overall) & 0.14 & 0.14 \\
\hline
\end{tabular}

Standard errors in parentheses. Classification of groups: 531, 65, and 89 participate in food-for-work (FFW) only, cash-forwork (CFW) only, and combination of FFW and CFW, respectively. * significant at $10 \%$; ** significant at 5\%; *** significant at $1 \%$

Links between FFW participation and production diversity

Table 10 summarizes the evidence regarding the link between FFW participation and production diversity. Results indicate that FFW participation has no detectable significant association with production diversity. This implies that FFW has no measurable influence on households' cropping decisions, and provides indirect evidence that the FFW program probably did not displace labor from on-farm agricultural production to an extent that it altered crop choices.

In terms of other household characteristics, households' diversity in crop production is positively associated with ownership of land area. This is an intuitive finding which shows that the production capacity of households, in terms of the number of crops planted, depends on land endowment. In relation to crop production capacity, Table 10 also shows that livestock ownership is positively associated with production diversity. 
Table 9 Effects of food-for-work income on household dietary diversity-continuous treatment

\begin{tabular}{|c|c|c|}
\hline & Fixed effects & Random effects \\
\hline \multirow[t]{2}{*}{ FFW income per adult equivalent (log) } & $0.14^{* * *}$ & $0.09^{* *}$ \\
\hline & $(0.05)$ & $(0.04)$ \\
\hline \multirow[t]{2}{*}{ Age of household head (years) } & -0.02 & $-0.02^{* * *}$ \\
\hline & $(0.02)$ & $(0.01)$ \\
\hline \multirow[t]{2}{*}{ Female-headed household (0/1) } & -0.13 & -0.43 \\
\hline & $(0.47)$ & $(0.28)$ \\
\hline \multirow[t]{2}{*}{ Education of head $(1 / 0)$} & $0.94^{* *}$ & $0.72^{* * *}$ \\
\hline & $(0.37)$ & $(0.24)$ \\
\hline \multirow[t]{2}{*}{ Adult female labor (\#) } & $0.28^{*}$ & $0.35^{* * *}$ \\
\hline & $(0.17)$ & $(0.12)$ \\
\hline \multirow[t]{2}{*}{ Adult male labor (\#) } & 0.12 & $0.22^{* *}$ \\
\hline & $(0.15)$ & $(0.10)$ \\
\hline \multirow[t]{2}{*}{ Children (\#) } & $0.20^{*}$ & $0.16^{* *}$ \\
\hline & $(0.11)$ & $(0.08)$ \\
\hline \multirow[t]{2}{*}{ Land area owned (Tsimdi) ${ }^{a}$} & 0.03 & $0.16^{* * *}$ \\
\hline & $(0.05)$ & $(0.03)$ \\
\hline \multirow[t]{2}{*}{ Livestock owned (TLUs) } & 0.00 & $0.13^{* * *}$ \\
\hline & $(0.05)$ & $(0.04)$ \\
\hline \multirow[t]{2}{*}{ Off-farm income (0/1) } & 0.29 & $0.44^{* *}$ \\
\hline & $(0.24)$ & $(0.20)$ \\
\hline \multirow[t]{2}{*}{2003} & $-1.33^{* * *}$ & $-1.12^{* * *}$ \\
\hline & $(0.29)$ & $(0.27)$ \\
\hline \multirow[t]{2}{*}{2006} & $0.58^{*}$ & $0.73^{* * *}$ \\
\hline & $(0.30)$ & $(0.27)$ \\
\hline \multirow[t]{2}{*}{2010} & $1.02^{* * *}$ & $1.16^{* * *}$ \\
\hline & $(0.29)$ & $(0.26)$ \\
\hline \multirow[t]{2}{*}{ Zone 2} & & $-0.81^{* *}$ \\
\hline & & $(0.33)$ \\
\hline \multirow[t]{2}{*}{ Zone 3} & & -0.23 \\
\hline & & $(0.34)$ \\
\hline \multirow[t]{2}{*}{ Zone 4} & & -0.42 \\
\hline & & $(0.34)$ \\
\hline \multirow[t]{2}{*}{ Zone 5} & & $-1.47^{* *}$ \\
\hline & & $(0.58)$ \\
\hline \multirow[t]{2}{*}{ Constant } & $13.72^{* * *}$ & $12.90^{* * *}$ \\
\hline & $(1.10)$ & $(0.72)$ \\
\hline Number of households & 1426 & 1426 \\
\hline Number of groups & 514 & 514 \\
\hline$R^{2}$ (overall) & 0.14 & 0.20 \\
\hline
\end{tabular}

Standard errors in parentheses. ${ }^{*}$ significant at $10 \%$; ${ }^{* *}$ significant at $5 \% ;{ }^{* *}$ significant at $1 \% .{ }^{\mathrm{a}} 1 \mathrm{Tsimdi}=0.25$ ha 


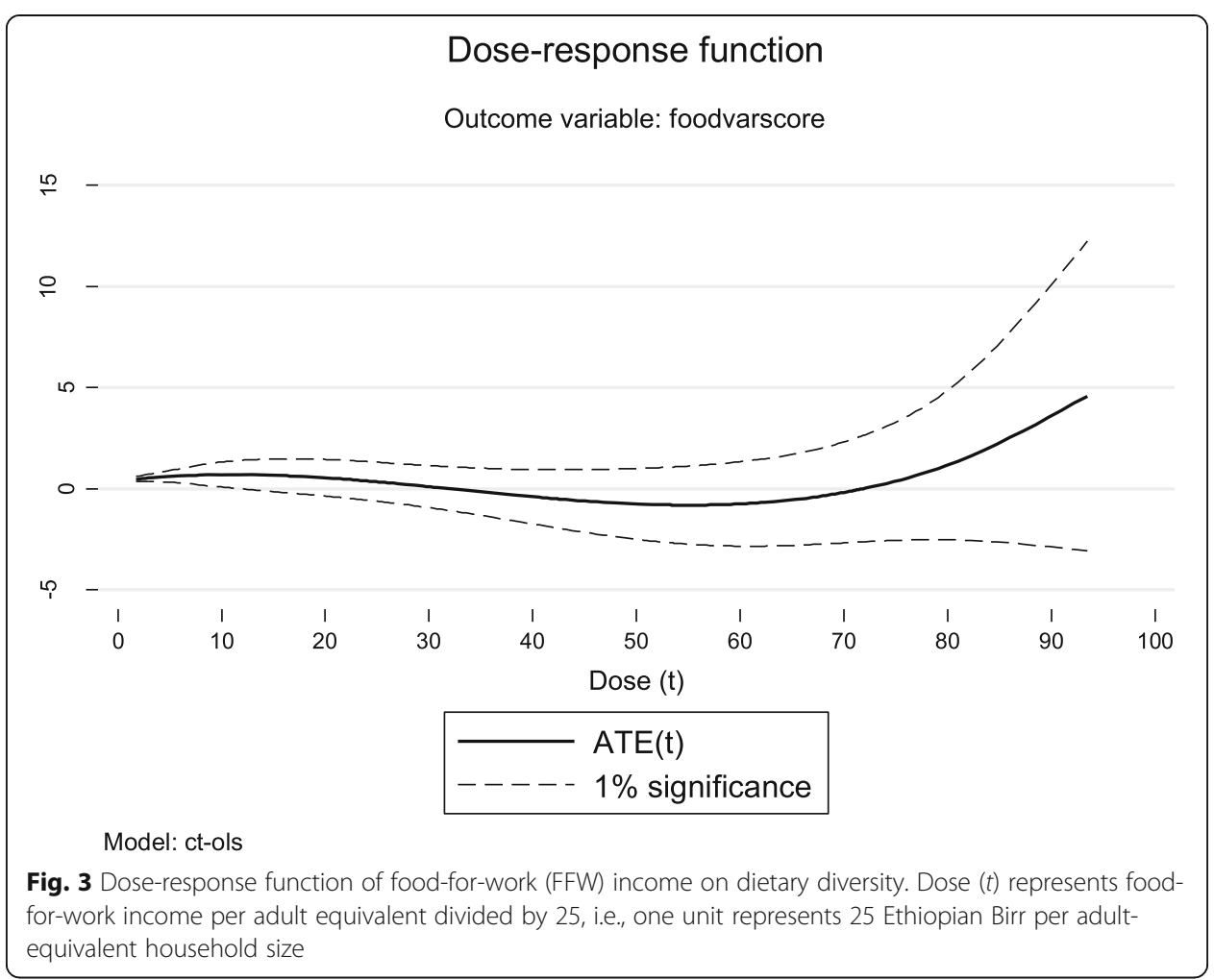

An interesting implication from this, in the context of Ethiopia, is that the diversity of crops grown depends on livestock ownership-perhaps because farm households in Ethiopia rely heavily on oxen for plowing. Further, results in Table 10 reveal that engaging in off-farm employment is positively and significantly correlated with production diversity in the sample.

\section{Examining alternative approaches}

This study undertakes five robustness checks to examine the consistency of the results. The first robustness check relies on using a balanced sample of households that appear in all survey rounds to estimate the main regressions. Findings show that major results are invariant to this change in sample and conclusions remain the same (see Table A3 in the Online Additional File 1).

Second, this study examines whether results remain consistent across two definitions of the FVS: (i) using nine food groups (i.e., the nine categories defined in Table 2); and (ii) excluding food items that have low nutritional value (i.e., oil and fats, sweets, spices and condiments) from the FVS. In the first case, a binary indicator for each food group is generated, with the indicator taking a value of 1 if a household consumed any food item in the food group (cereals; legumes, nuts, and seeds; vegetables, meat; eggs; milk; oil and fats; sweets; spices and condiments). The household dietary diversity score is then calculated by taking the sum across groups, with the score ranging from 1 to 9 . In the second case, food items that have low nutritional value (oil and fats; sweets; spices and condiments) are excluded from the FVS. Regression patterns are similar (see Table A4 in the Online Additional File 1) and indicate that FFW participation remains 
Table 10 Effects of food-for-work participation on production diversity

\begin{tabular}{|c|c|c|c|}
\hline & $\begin{array}{l}\text { Fixed effects } \\
\text { Model } 2 \mathrm{~A}\end{array}$ & $\begin{array}{l}\text { Random effects } \\
\text { Model 2B }\end{array}$ & $\begin{array}{l}\text { DID }^{\mathrm{b}} \\
\text { Model 2C }\end{array}$ \\
\hline \multirow[t]{2}{*}{ FFW participant $(0 / 1)$} & 0.04 & 0.05 & -0.06 \\
\hline & $(0.08)$ & $(0.06)$ & $(0.06)$ \\
\hline \multirow[t]{2}{*}{ Age of household head (years) } & -0.003 & 0.003 & -0.004 \\
\hline & $(0.005)$ & $(0.002)$ & $(0.005)$ \\
\hline \multirow[t]{2}{*}{ Female-headed household (0/1) } & 0.10 & -0.04 & 0.06 \\
\hline & $(0.16)$ & $(0.08)$ & $(0.14)$ \\
\hline \multirow[t]{2}{*}{ Education of head $(0 / 1)$} & 0.05 & $0.16^{* *}$ & -0.07 \\
\hline & $(0.13)$ & $(0.07)$ & $(0.10)$ \\
\hline \multirow[t]{2}{*}{ Adult female labor (\#) } & -0.04 & 0.03 & -0.05 \\
\hline & $(0.06)$ & $(0.04)$ & $(0.05)$ \\
\hline \multirow[t]{2}{*}{ Adult male labor (\#) } & 0.02 & 0.04 & 0.01 \\
\hline & $(0.05)$ & $(0.03)$ & $(0.04)$ \\
\hline \multirow[t]{2}{*}{ Children (\#) } & 0.02 & $0.06^{* *}$ & -0.01 \\
\hline & $(0.04)$ & $(0.02)$ & $(0.03)$ \\
\hline \multirow[t]{2}{*}{ Land area owned $\left(\right.$ Tsimdi) ${ }^{a}$} & $0.08^{* * *}$ & $0.04^{* * *}$ & $0.05^{* * *}$ \\
\hline & $(0.02)$ & $(0.01)$ & $(0.01)$ \\
\hline \multirow[t]{2}{*}{ Livestock owned (TLUs) } & $0.04^{* *}$ & $0.05^{* * *}$ & -0.01 \\
\hline & $(0.02)$ & $(0.01)$ & $(0.01)$ \\
\hline \multirow[t]{2}{*}{ Off-farm income (0/1) } & $0.16^{* *}$ & 0.10 & 0.09 \\
\hline & $(0.08)$ & $(0.06)$ & $(0.06)$ \\
\hline \multirow[t]{2}{*}{2003} & $-0.19^{*}$ & $-0.19^{* *}$ & \\
\hline & $(0.10)$ & $(0.09)$ & \\
\hline \multirow[t]{2}{*}{2006} & 0.12 & $0.16^{*}$ & $0.36^{* * *}$ \\
\hline & $(0.10)$ & $(0.09)$ & $(0.11)$ \\
\hline \multirow[t]{2}{*}{2010} & 0.14 & $0.15^{*}$ & $0.36^{* * *}$ \\
\hline & $(0.10)$ & $(0.09)$ & $(0.09)$ \\
\hline \multirow[t]{2}{*}{ Zone 2} & & 0.01 & \\
\hline & & $(0.09)$ & \\
\hline \multirow[t]{2}{*}{ Zone 3} & & $0.29^{* * *}$ & \\
\hline & & $(0.09)$ & \\
\hline \multirow[t]{2}{*}{ Zone 4} & & 0.04 & \\
\hline & & $(0.09)$ & \\
\hline \multirow[t]{2}{*}{ Zone 5} & & $-0.51^{* * *}$ & \\
\hline & & $(0.18)$ & \\
\hline \multirow[t]{2}{*}{ Constant } & $2.10^{* * *}$ & $1.69^{* * *}$ & $2.38^{* * *}$ \\
\hline & $(0.38)$ & $(0.21)$ & $(0.07)$ \\
\hline Number of obs. & 1426 & 1426 & 912 \\
\hline Number of groups & 514 & 514 & 371 \\
\hline$R^{2}$ (overall) & 0.05 & 0.10 & 0.04 \\
\hline
\end{tabular}

Standard errors in parentheses. ${ }^{*}$ significant at $10 \%$; ${ }^{*}$ significant at $5 \%$; ${ }^{* *}$ significant at $1 \% .{ }^{\mathrm{a}} 1 \mathrm{Tsimdi}=0.25 \mathrm{ha}$; Hausman test $\left(x^{2}=27.0, p\right.$-value $\left.=0.01\right) ;{ }^{b}$ In the DID model, standard errors are clustered by household ID 
significantly associated with dietary diversity, regardless of the FVS definition used, although the magnitude of the influence is smaller in the case of the more restricted FVS (see Table A5 in the Online Additional File 1).

Third, an alternative definition of production diversity is used by including the number of livestock species in calculating the score, thereby reflecting the number of both crop and animal species households produce. Results lead to similar conclusions as from the main model, except for a difference in the DID estimation (see Table A6 in the Online Additional File 1). Fourth, the production diversity model is estimated incorporating the one-year lagged FFW participation indicator as a possible driver of the current production diversity score. This allows examining if previous participation in FFW influences crop production in the following year. Results show that lagged FFW participation does not have a significant association with current production diversity, yielding results similar to the main model (see Table A7 in the Online Additional File 1).

A fifth and final robustness check was undertaken by controlling for potential attrition bias in the data. An attrition probit model was first estimated using a binary indicator taking a value one if the household does not belong to the balanced panel and zero otherwise as a dependent variable (see Table A8 in the Online Additional File 1). The Inverse Mills Ratio (IMR) was then calculated based on the prediction from this probit model. Estimating fixed effects regression models, including the IMR as a variable to control for the latent characteristics of attritors, is the last step for checking the attrition bias. According to the results of this model, households that are part of the balanced panel do not differ from the rest of the households in most of the socioeconomic characteristics (see Table A8 in the Online Additional File 1). Differences exist in the age of the household head and the number of adult male members. However, the IMR is not statistically significant at standard test levels when included in the main regression. Point estimates remain similar in sign, magnitude, and significance to those in a regression without the correction (Table A9, Online Additional File 1). This implies that results are not measurably affected by any attrition bias. ${ }^{10}$

\section{Limitations of the study}

The PSNP was not static over the course of the first phase (2005-2010), either in terms of targeting or implementation. Subsequent phases also differed over time, for example by adding new components to the existing program. For example, the third phase (PSNP 3) was gender and child sensitive such that it allowed temporary status change for pregnant and lactating mothers from public work programs to free food and cash (World Bank 2016). PSNP 4 incorporated nutrition education and direct investments in nutrition as components. Particularly, PSNP 4 provides $15 \mathrm{~kg}$ of wheat and $4 \mathrm{~kg}$ of pulses as food payments (Government of Ethiopia 2014; World Bank 2016). This study has focused on the first phase of the program and therefore subsequent program changes do not affect the impacts evaluated here. However, it is acknowledged that one limitation of this study is that program changes that occurred during the implementation of the first phase are not captured. Future research incorporating longer panels of data could, in theory, examine whether nutritional outcomes were affected by changes

\footnotetext{
${ }^{10}$ Regression results using Poisson models are similar to the linear models in terms of signs and significance (Tables A10 and A11, Online Additional file 1).
} 
within and between different phases of the PSNP, for example, in terms of targeting, implementation, or added components.

\section{Conclusions}

This study examines whether Ethiopia's FFW programs contribute to the variety in food consumption and crop production. Based on four waves of survey data (2001, 2003, 2006, and 2010), findings show that participating in FFW programs improved dietary diversity. The association remains positive but smaller in magnitude when food items provided by the FFW are excluded from the food variety score (FVS). Further disentangling the food groups consumed among participants and non-participants in the FFW programs, results show that the observed difference in cereal consumption between the two groups disappears when wheat is excluded from the FVS calculation. An implication is that FFW improves dietary diversity when the food item is not part of the staple diet. Results reveal that FFW slightly crowds in consumption of other food items, possibly enhancing food security of poor rural households. A policy implication is that, by providing food items that are not part of the staple diet as part of a safety net program, the intervention will likely not only assure food availability but also improve dietary diversity. It is possible that the list of potential food items provided under FFW programs is restricted due to the cost and perishability of some food groups. Nevertheless, food-based transfer programs may want to consider providing a wider basket of food items. In truth, later phases of the PSNP (e.g., PSNP 4) have moved toward providing a more diverse basket of food items, for example by providing wheat and pulses. These results highlight the value of this approach. Food items from other groups might also be considered to further improve dietary quality and magnify nutritional benefits of the program.

Results from a dose-response model using a continuous treatment show that a higher intensity of FFW participation is associated with more diversified food consumption. Findings further reveal that FFW participation was uncorrelated with production diversity, which suggests that such programs may not necessarily compete for agricultural labor, at least not to the extent that households are making discernable changes in crop mix.

\section{Abbreviations}

FFW: Food-for-work; CFW: Cash-for-work; PSNP: Productive Safety Net Program; FVS: Food Variety Score; PDS: Production Diversity Score

\section{Supplementary Information}

The online version contains supplementary material available at https://doi.org/10.1186/s40100-021-00189-1.

Additional File 1.

\section{Acknowledgements}

Data collection was undertaken by the Norwegian University of Life Sciences in collaboration with Mekelle University. The authors acknowledge numerous students at these universities that contributed to the collection, cleaning, and organization of the data. We thank seminar participants at GlobalFood Research Training Group and the CSAE 2018 Conference on Economic Development in Africa for valuable comments. 
survey instruments and supervised students and subsequent rounds of data collection. STH also designed the study. All authors read and approved the final version.

\section{Funding}

STH secured funding for the collection of panel data from the Research Council of Norway, the Norwegian Ministry of Foreign Affairs, and the Norwegian Agency for Development Cooperation (NORAD); BLD received financial support for this work from the Deutsche Forschungsgemeinschaft (German Research Foundation) as part of the GlobalFood program; and GES acknowledges support from the Purdue Policy Research Institute and the Feed the Future Innovation Lab for Nutrition, which is funded by the United States Agency for International Development. Findings and opinions expressed in this manuscript do not necessarily reflect the opinions of the funding sources, and the funding agencies were not involved in the analysis or interpretation of results. Open Access funding enabled and organized by Projekt DEAL.

\section{Availability of data and materials}

The datasets analyzed can be obtained from the corresponding author on reasonable request.

\section{Declarations}

\section{Competing interests}

The authors do not have any conflicts of interest.

\section{Author details}

${ }^{1}$ Department of Agricultural Economics and Rural Development, University of Goettingen, Platz der Goettinger Sieben 5, 37073 Goettingen, Germany. ${ }^{2}$ Department of Agricultural Economics and Purdue Policy Research Institute, Purdue University, 403 West State Street, West Lafayette, IN 47907-2056, USA. ${ }^{3}$ School of Economics and Business, Norwegian University of Life Sciences, P.O. Box 5003, 1432 Ås, Norway.

Received: 12 July 2019 Revised: 9 October 2020

Accepted: 15 April 2021 Published online: 22 July 2021

\section{References}

Abdulai A, Barrett C, Hoddinott J (2005) Does food aid really have disincentive effects? New evidence from Sub-Saharan Africa. World Development 33(10):1689-1704. https://doi.org/10.1016/j.worlddev.2005.04.014

Adato M, Hoddinott J (2008) Social Protection: Opportunities for Africa. International Food Policy Research Institute (IFPRI) Policy Brief 5. September 2008.

Alderman H, Mustafa M (2013) Social protection and nutrition. Preparatory technical meeting for the International Conference on Nutrition (ICN2), November 13-15, 2013, Rome. Available at: http://www.fao.org/fileadmin/user_upload/a gn/pdf/PTM-ICN2_07_Rev1_Alderman_Full_Paper_2013-11-22.pdf. Accessed 16 Feb 2017.

American Institutes for Research (AIR) (2013) Zambia's child grant program: 24-month impact report, Washington D.C Available at: https:/www.air.org/sites/default/files/downloads/report/Zambia_Child_Grant_Program_Report_20131_0.pdf Access 6 June 2017

Ayalew W, King JM, Bruns E, Rischkowsky B (2003) Economic evaluation of smallholder subsistence livestock production: lessons from an Ethiopian goat development program. Ecol Econ 45(3):473-485. https://doi.org/10.1016/50921-8009(03)00098-3

Bailey S (2013) The impact of cash transfers on food consumption in humanitarian settings: A review of evidence. Study for the Canadian Foodgrains Bank Available at: https://reliefweb.int/sites/reliefweb.int/files/resources/cfgb---impact-of-cashtransfers-on-food-consumption-may-2013-final-clean.pdf. Accessed 26 Apr 2019.

Barrett CB, Holden S, Clay DC (2005) Can Food for work programmes reduce vulnerability? In: Dercon S(ed) Insurance against poverty. Oxford University Press, Oxford

Berhane G, Devereux S, Hoddinott J, Hoel J, Roelen K, Abay K, Kimmel M, Ledlie N, Woldu T (2015) Evaluation of the social cash transfers pilot programme: Tigray region, Ethiopia (Endline Report). International Food Policy Research Institute, Washington D.C Available at: http://www.fao.org/fileadmin/user_upload/p2p/Publications/UNICEF_Tigray_Endline_Report. pdf. Accessed 6 June 2017

Berhane G, Gilligan DO, Hoddinott J, Kumar N, Taffesse AS (2014) Can social protection work in Africa? The Impact of Ethiopia's Productive Safety Net Programme. Econ Dev Cult Change 63(1):1-26. https://doi.org/10.1086/677753

Berhane G, Hoddinott J, Kumar N, Tafesse AS, Diressie MT, Yohannes Y, Sabates-Wheeler R, Handino M, Lind J, Tefera M, Sima F (2013) Evaluation of Ethiopia's food security program: documenting progress in the implementation of the productive safety nets programme and the household asset building programme. Ethiopia Strategy Support Program II, ESSP II-EDRI Report, International Food Policy Research Institute, Washington, D.C Available at: https://essp.ifpri.info/files/2013/05/ ESSPII_EDRI_Report_PSNP.pdf. Accessed 1 June 2017.

Berlie AB (2014) The role of productive safety nets in improving household food dietary diversity in the Amhara Region of Ethiopia: a case study on Lay Gayint District. Ethiopian J Health Dev 28(3):191-201

Bezu S, Holden S (2008) Can food-for-work encourage agricultural production? Food Policy 33(6):541-549. https://doi.org/10.1 016/.ffoodpol.2008.06.004

Burchi F, Scarlato M, d'Agostino G (2016) Addressing food insecurity in sub-Saharan Africa: the role of cash transfers. DIE Discussion Paper 17/2016. Available at: https://www.die-gdi.de/uploads/media/DP_17.2016.pdf Access 16 Feb 2017.

Caeyers B, Dercon S (2012) Political connections and social networks in targeted transfer programmes: Evidence from rural Ethiopia. Econ Dev Cult Change 60(4):639-675. https://doi.org/10.1086/665602

Cerulli G (2015) Ctreatreg: Command for fitting dose-response models under exogenous and endogenous treatment. Stata J 15(4):1019-1045. https://doi.org/10.1177/1536867X1501500405

Cochrane L, O'Regan D (2016) Legal harvest and illegal trade: Trends, challenges, and options in khat production in Ethiopia. Int J Drug Policy 30:27-34. https://doi.org/10.1016/j.drugpo.2016.02.009 
Coll-Black S, Gilligan DO, Hoddinott J, Kumar N, Taffesse AS, Wiseman W (2011) Targeting food security interventions when "everyone is poor": The case of Ethiopia's Productive Safety Net Programme. Ethiopia Strategy Support Program II (ESSP II) Working Paper 24. International Food Policy Research Institute, Addis Ababa Available at: https://pdfs.semanticscholar. org/5e7c/8f97f9e9e4ed9c80e42b584cc59144cbd155.pdf. Accessed 26 May 2014.

de Groot R, Palermo T, Handa S, Ragno LP, Peterman A (2017) Cash transfers and child nutrition: Pathways and impacts. Dev Policy Rev 35(5):621-643. https://doi.org/10.1111/dpr.12255

Dercon S (2011) Social Protection, Efficiency and Growth. Centre for the Study of African Economies (CSAE) Working Paper WPS /2011-17. Oxford.

Devereux S (2001) Livelihood insecurity and social protection: a re-emerging issue in rural development. Development policy review, 19(4), 507-519.

Food and Agriculture Organization (FAO) (2005) A historical background on food aid and key milestones. Committee on Commodity Problems, Rome Sixty-fifth Session. 11-13 April 2005, Italy. Available at: http://www.fao.org/3/J4865e/J4865e htm Access 14 Apr 2020

Food and Agriculture Organization (FAO) (2011) Guidelines for measuring household and individual dietary diversity. Food and Agriculture Organization of the United Nations Available at: http://www.fao.org/3/a-i1983e.pdf Access 27 June 2016

Gebissa E (2008) Scourge of life or an economic lifeline? Public discourses on khat (Catha edulis) in Ethiopia. Subst Use Misuse 43(6):784-802. https://doi.org/10.1080/10826080701738950

Gelan AU (2007) Does Food Aid Have Disincentive Effects on Local Production? A General Equilibrium Perspective on Food Aid in Ethiopia. Food Policy 32(4):436-458. https://doi.org/10.1016/j.foodpol.2006.09.001

Gilligan DO, Hoddinot J, Taffesse AS (2008) The impact of Ethiopia's Productive Safety Net Program and its linkages. IFPRI Discussion Paper no. 00839, International Food Policy Research Institute, Washington, DC Available at: http://cdm15738. contentdm.oclc.org/utils/getfile/collection/p15738coll2/id/29532/filename/29533.pdf. Accessed 26 May 2014.

Gilligan DO, Hoddinott J (2007) Is There Persistence in the Impact of Emergency Food Aid? Evidence on Consumption, Food Security, and Assets in Rural Ethiopia. Am J Agric Econ 89(2):225-242. https://doi.org/10.1111/ j.1467-8276.2007.00992.x

Government of Ethiopia (2009) Productive Safety Net Program. Food Security Program 2010-2014. Ministry of Agriculture and Rural Development. August 2009, Addis Ababa

Government of Ethiopia (2014) Productive Safety Net Program Phase IV. Program Implementation Manual. Ministry of Agriculture, Addis Ababa December 2009

Hagos F, Holden S (2002) Incentives for conservation in Tigray, Ethiopia: Findings from a household survey. Department of Economics and Social Sciences, Agricultural University of Norway, Unpublished.

Hidrobo M, Hoddinott J, Kumar N, Meghan O (2018) Social protection, food security, and asset formation. World Dev 101:88103. https://doi.org/10.1016/j.worlddev.2017.08.014

Hidrobo M, Hoddinott J, Peterman A, Margolies A, Moreira V (2014) Cash, food, or vouchers? Evidence from a randomized experiment in northern Ecuador. J Dev Econ 107:144-156. https://doi.org/10.1016/j.jdeveco.2013.11.009

Hirvonen K, Taffesse A, Worku Hassen I (2016) Seasonality and household diets in Ethiopia. Public Health Nutr 19(10):17231730. https://doi.org/10.1017/S1368980015003237

Hoddinott J, Skoufias E (2004) The impact of PROGRESA on food consumption. Econ Dev Cult Change 53(1):37-61. https:// doi.org/10.1086/423252

Hoddinott J, Wiesmann D (2008) The impact of conditional cash transfer programs on food consumption in Honduras, Mexico and Nicaragua. Available at https://ssrn.com/abstract=1269417

Hoddinott JF, Headey DD, Dereje M (2014) Cows, missing milk markets and nutrition in rural Ethiopia. ESSP II Working Paper 63. International Food Policy Research Institute (IFPRI) and Ethiopian Development Research Institute (EDRI), Washington, D.C. and Addis Ababa Available at: http://ebrary.ffpri.org/cdm/ref/collection/p15738coll2/id/128038 Access 5 Mar 2018

Jayne TS, Strauss J, Yamano T, Molla D (2001) Giving to the poor? Targeting of food aid in rural Ethiopia. World Dev 29(5): 887-910. https://doi.org/10.1016/S0305-750X(01)00011-0

Merttens F, Hurrell A, Manzi M, Attah R, Farhat M, Kardan A, MacAuslan I (2013) Kenya Hunger Safety Net Programme monitoring and evaluation component (Impact Evaluation Final Report 2009- 2012). Oxford Policy Management, Oxford Available at https:/assets.publishing.service.gov.uk/government/uploads/system/uploads/attachment_data/file/284251/ Kenya-Hunger-Safety-Net-Programme-2009-2012.pdf Access 6 June 2017

Miller CM, Tsoka M, Reichert K (2011) The impact of the social cash transfer scheme on food security in Malawi. Food Policy 36(2):230-238. https://doi.org/10.1016/.jfoodpol.2010.11.020

Nair MK, Augustine LF, Kanapur A (2016) Food-based interventions to modify diet quality and diversity to address multiple micronutrient deficiency. Front Public Health 3(277). https://doi.org/10.3389/fpubh.2015.00277

Nega F, Mathiis E, Deckers J, Haile M, Nyssen J, Tollens E (2010) Rural poverty dynamics and impact of intervention programs upon chronic and transitory poverty in northern Ethiopia. Afr Dev Rev 2(1):92-114

Rahmato D, Pankhurst A, van Uffelen J (eds) (2013) Food security, safety nets and social protection in Ethiopia. Forum for Social Studies, Addis Ababa

Rogers BL, Coates J (2002) Food-based safety nets and related programs. Discussion Paper No. 12. The Gerald J. and Dorothy R. Friedman School of Nutrition Science and Policy. Food Policy and Applied Nutrition Program. Available at: https://pdfs. semanticscholar.org/511c/25c59056ad00d6fdeaecb9e9306ac8cd4923.pdf Access 13 Feb 2017.

Ruel MT (2002) Is dietary diversity an indicator of food security or dietary quality? A review of measurement issues and research needs. FCND Discussion Paper No. 140. International Food Policy Research Institute, Washington D.C Available at: http://ebrary.fpri.org/utils/getfile/collection/p15738coll2/id/66936/filename/66937.pdf Access 16 Feb 2017

Sabates-Wheeler R, Devereux S (2010) Cash transfers and high food prices: Explaining outcomes on Ethiopia's Productive Safety Net Program. Food Policy 35(4):274-285. https://doi.org/10.1016/j.foodpol.2010.01.001

Tadesse G, Shively G (2009) Food aid, food prices, and producer disincentives in Ethiopia. Am J Agri Econ 91(4):942-955. https://doi.org/10.1111/j.1467-8276.2009.01324x

Tigray Food Security Task Force (2009) Productive Safety Net Program. First Quarter Report. October, 2009.

Uraguchi ZB (2011) Rural income transfer programs and rural household food security in Ethiopia. J Asian Afr Stud 47(1):33-51 
Wooldridge JM (2010) Econometric analysis of cross section and panel data. The MIT Press, Cambridge

World Bank (2016) Implementation completion and results report. Productive Safety Net APL III Project. Social Protection and Labor Global Practice, Africa Region Available at: http://documents.worldbank.org/curated/en/229421467954050889/pdf/ ICR3659-P113220-Box396273B-PUBLIC-disclosed-7-6-16.pdf Access 31 Jan 2019

World Food Program (2015) How WFP supported dietary diversification of vulnerable Ecuadorians and Colombian refugees. A case study on nutrition-sensitive programming in a middle income country. World Food Program Available at: https:// documents.wfp.org/stellent/groups/public/documents/newsroom/wfp274579.pdf?_ga=1.206469972.63341403.14623472 64 Access 14 Apr 2020

World Food Program (2017) The Potential of Food Assistance for Assets (FFA) to empower women and improve women's nutrition: A five country study. Final Report. Available at: https://reliefweb.int/sites/reliefweb.int/files/resources/152024332 8.WFP-0000023821.pdf. Access 14 Apr 2020.

World Food Program (2019) Food Assistance for Assets (FFA) in Southern Africa. WFP Fact Sheet. Available at: https://docs. wfp.org/api/documents/WFP-0000110208/download/?_ga=2.43704684.816753335.1588350429-929645821.1586513630 Access 1 May 2020

Zhou AC, Hendriks SL (2017) Does food assistance improve recipients' dietary diversity and food quality in Mozambique? Agrekon 56(3):248-262. https://doi.org/10.1080/03031853.2017.1360783

\section{Publisher's Note}

Springer Nature remains neutral with regard to jurisdictional claims in published maps and institutional affiliations.

Submit your manuscript to a SpringerOpen ${ }^{\circ}$ journal and benefit from:

- Convenient online submission

- Rigorous peer review

- Open access: articles freely available online

- High visibility within the field

- Retaining the copyright to your article

Submit your next manuscript at $>$ springeropen.com 